\title{
CLINICAL CASE OF GENERAL SOMATIC COMPLAINTS IN 47 Y.O. FEMALE
}

Reng G. J., Kanishcheva O. V., Zhuravka N. V., Yabluchansky M. I.

V. N. Karazin Kharkiv National University, Kharkiv, Ukraine

A clinical case of general somatic complaints in 47 y.o. female, presenting for several years has described. Patient F., presents with uncertain complaints of general character - tiredness, general weakness, loss of energy. During the biennium was examined and treated by gynecologist, endocrinologist, cardiologist, gastroenterologist with no benefit. Anamnesis vita is significant for uterine fibroid. After thorough interviewing was found that patient was done ECG, EchoCG, gastroscopy, thyroid tests but no CBC, urinalysis, general biochemical panel during this two years. The $\mathrm{CBC}$ results were stunning and gave answers to all questions.

KEY WORDS: clinical case, anemia, complete blood count

\section{КЛІНІЧНИЙ ВИПАДОК ЗАГАЛЬНОСОМАТИЧНИХ СКАРГ У ПАЦІЕНТКИ 47 РОКІВ}

Рен Г. Дж., Каніщева О. В., Журавка Н. В., Яблучанський М. І.

Харківський національний університет імені В. Н. Каразіна, м. Харків, Україна

Описано випадок загальносоматичних скарг у пацієнтки 47-річного віку, що турбували протягом декількох років. Пацієнтка Ф., скаржиться на загальну слабкість, втомлюваність, втрату енергії. Протягом двох років зверталася до гінеколога, ендокринолога, кардіолога, гастроентеролога, була обстежена цими спеціалістами. Призначене лікування виявилося неефективним. Багато років страждає на фіброміому матки і з цього приводу щорічно відвідує гінеколога. Після ретельного опитування було виявлено, що за ці роки пацієнтці було зроблено ЕКГ, УЗД серця, гастроскопію, визначення рівня гормонів щитовидної залози у крові, але жодного клінічного аналізу крові, сечі або загального біохімічного. Перші ж результати клінічного аналізу крові були приголомшливі та одразу дали відповіді на всі питання.

КЛЮЧОВІ СЛОВА: клінічний випадок, анемія, клінічний аналіз крові

\section{КЛИНИЧЕСКИЙ СЛУЧАЙ ОБЩЕСОМАТИЧЕСКИХ ЖАЛОБ У ПАЦИЕНТКИ 47-МИ ЛЕТ}

Рен Г. Дже, Канищева Е. В., Журавка Н. В., Яблучанский Н. И.

Харьковский национальный университет имени В. Н. Каразина, г. Харьков, Украина

Описан случай общесоматических жалоб в течение нескольких лет у пациентки 47-летнего возраста. Пациентка Ф., жалуется на общую слабость, утомляемость. В течение двух лет обращалась к гинекологу, эндокринологу, кардиологу, гастроэнтерологу, была обследована этими специалистами. Назначенное лечение оказалось неэффективным. В анамнезе жизни - фибромиома матки, в связи с чем ежегодно посещает гинеколога. После тщательного опроса было выявлено, что за эти годы пациентке было проведено ЭКГ, УЗИ сердца, гастроскопия, определение уровня гормонов щитовидной железы в крови, но не выполнено ни одного клинического анализа крови, мочи или общего биохимического исследования. Первые же результаты клинического анализа крови сразу дали ответы на все вопросы.

КЛЮЧЕВЫЕ СЛОВА: клинический случай, анемия, клинический анализ крови

\section{INTRODUCTION}

With age the comorbidity problem becomes more pressing issue [1-2]. It seems difficult to interpret complaints such as fatigue, general weakness, malaise because of their uncertainty and inability to determine at a glance problem with which body system produce them. 
Specialized doctors tend to interpret such complaints in favor of «their» diagnosis, which, in some cases, prevents them to see the whole problem and treat effectively.

We present the clinical case of general somatic complaints in middle age woman, presenting for several years. Patient was examined and treated by four specialized doctors without significant effect, and finally it ended up in banal cause.

\section{CLINICAL CASE}

Patient F., female, 47 y.o., complains of tiredness, general weakness, low energy, heaviness in the legs. Also reports dyspnea and tachycardia with low physical exertion, dizziness in the metro. Heart intermissions, chest pain, cough denies. She also denies edema but reports face and legs puffiness. Her BP varies between $100-110 / 70 \mathrm{~mm} \mathrm{Hg}$, but sometimes, mostly after menstruation, falls up to $70 / 40 \mathrm{~mm} \mathrm{Hg}$. Low BP accompanied with light dizziness but not affects the ordinary activity. Review of digestive system revealed the lack of appetite. Review of urinary system was significant for periodical imperative urge to urinate without any evident provoking factor. Urination is painless, of ordinary frequency. No changes in urine volume or color. Pain in the lumbar region denies. Menstrual periods are regular, 23 days, bleedings are painless, 2-3 days, not heavy. Since 2008 to 2012 had scanty bleedings between menstruations, now bleedings between menstruations denies. Review of musculoskeletal system was unremarkable. Reports slight reduction in work capacity.

Presenting complaints of tiredness and general weakness gradually increased over 2 years. In January 2017 occurred dyspnea, dizziness, uncertain pain in the abdomen. 19.01.2017 was examined by gastroenterologist. After ultrasound of the abdominal cavity (19.01.2017) and gastroscopy (19.01.2017) the diagnosis of gastropathy, cholecystopathy, micronephrolithiasis was made. Mebeverinum and pancreatinum was admitted for 10 days, with no effect. In May 2017 dyspnea and dizziness became more prominent. Sense of heaviness in the legs, face puffiness occurred. 05.05.2017 was examined by cardiologist. The diagnoses of cardiopsychoneurosis, mitral valve prolapse of $2^{\text {nd }}$ degree, HF 0 was made. Patient was treated with «Detralex», asparaginat $\mathrm{K}-\mathrm{Mg}$ and trimetazidine, with short and insignificant effect. A tentative diagnosis of hypothyroidism was made. Thyroid tests and endocrinologist consultation was recommended but patient refuse it. In September 2017 dyspnea, dizziness, heaviness in the legs became worth, lack of appetite, hands and legs puffiness occurred. Appealed to Internal Medicine department of the V.N. Karazin Kharkiv National University.

Anamnesis vita is significant for uterine fibroid and thyroid hyperplasia. 2010 Fractional uterus curettage, submucosal fibroid was removed; 2012 - hysteroscopy, polypectomy. Family history is negative for autoimmune disorders, cancer, early CVD, genetic abnormalities. Currently takes no medications, vitamin supplements or over the counter drugs.

On examination light yellowness of the skin, scleras are white. Visible mucosa is moist, of normal color. BMI $20 \mathrm{~kg} / \mathrm{m} 2$. Puffy face, hands and ankles. Thyroid hyperplasia of $1^{\text {st }}$ degree, thyroid gland is painless to palpation. Heart borders are not expanded, sounds are muffled, rhythm regular, systolic murmur at the heart apex. HR 86 bpm. BP supine 130/90, standing $120 / 70$. Otherwise physical examination was unremarkable.

A tentative diagnosis was made: mitral valve prolapse, $2^{\text {nd }}$ degree. Heart failure? Anemia?

CBC showed $\mathrm{Hb} 47 \mathrm{~g} / \mathrm{l}, \mathrm{RBC} 2,5 \times 10^{12} / \mathrm{L}$, color index 0,56, ESR $22 \mathrm{~mm} / \mathrm{h}$, Hct 17. Blood smear: erythrocytes were mainly hypochromic, pronounced anisocytosis and poikilocytosis were present; normoblasts were not revealed, WBC morphology was within normal limits. Urinalysis: specific gravity 1016, negative for protein, glucose, ketone bodies, erythrocytes, bacteria; squamous and transitional epithelium was present in some places. Blood tests were significant for creatininemia $(116,7 \mu \mathrm{mol} / \mathrm{l})$ and hypokaliemia $(3,0 \mathrm{mmol} / \mathrm{l})$. GFR, estimated by Cockcroft-Gault equation showed moderate decline $\left(46 \mathrm{ml} / \mathrm{min} / 1,73 \mathrm{~m}^{2}\right)$.Total protein, albumin, urea, fasting glucose, sodium and thyroid hormones were within normal ranges. ECG showed low voltage, anterior fascicular of left bundle branch block.

Thus, the hypochromic anemia was reviled and additional tests - serum iron and serum ferritin - were done. The both were decreased (iron $7,5 \mu \mathrm{mol} / 1$, ferritin $9,45 \mathrm{ng} / \mathrm{ml}$ ), which is fit with iron deficiency anemia. Uterine fibroid was thought the most likely cause. Patient was referred to gynecologist for 
hospitalization and further management with the diagnosis: Iron deficiency anemia, severe degree. Uterine fibroid. Mitral valve prolapse, $2^{\text {nd }}$ degree. Thyroid hyperplasia, $1^{\text {st }}$ degree, euthyroid state.

Follow-up. Patient was hospitalized in the gynecological department of the regional hospital. She was given RBC transfusion and, after $\mathrm{Hb}$ was increased, underwent a uterus extirpation. Was discharged from the hospital with no complaints, $\mathrm{Hb}$ of $100 \mathrm{~g} / \mathrm{L}$, normal renal function tests and potassium level. She was advised to take oral iron and after a month her $\mathrm{Hb}$ was $129 \mathrm{~g} / \mathrm{l}, \mathrm{RBC} 4 \times 10^{12} / \mathrm{L}$, ESR $6 \mathrm{~mm} / \mathrm{h}$.

\section{CONCLUSIONS}

The cause of our patient's condition was iron deficiency anemia (IDA). It remains a widely underdiagnosed and unappreciated women's health issue, affecting women of all ages [3-4]. Complaints presented by our patient were not specific and are typical for many diseases. Doctors can't focus only on their specialization and should look at a patient in hole, but not at «their» specialized field. None of the specialized doctors who observed our patient prescribed a $\mathrm{CBC}$, thus the cause was not reviled and treatment was not effective.

Clinicians should routinely identify and treat IDA, thereby decreasing its negative impact on health and quality of life of women.

\section{REFERENCES}

1. Non-cardiovascular comorbidity, severity and prognosis in non-selected heart failure populations: A systematic review and meta-analysis / C. A. Rushton, D. K. Satchithananda, P. W. Jones, U. T. Kadam. // Int J Cardiol. - 2015. -No. 196. - P. 98-106.

2. The role of iron deficiency anemia in patients with chronic heart failure in the example of a clinical case / M. D. Nsikak-Abasi, K. I. Kornieieva, D. I. Stehnyi, M. M. Lebedinska. // The Journal of V. N. Karazin Kharkiv National University, series «Medicine». - 2017. -No. 33. - P. 86-90.

3. Iron deficiency anemia in women: a practical guide to detection, diagnosis, and treatment / [A. J. Friedman, A. Shander, S. R. Martin et al.]. // Obstet Gynecol Surv. - 2015. - No.70. - P. 342-353.

4. Camaschella C. Iron deficiency: new insights into diagnosis and treatment / C. Camaschella // Hematology Am Soc Hematol Educ Program. - 2015. -No. 2015. - P. 8-13. 